\title{
S-LCA Indicators as Employee Motivation Factors
}

\author{
By Jan Vavra ${ }^{1}$, Michal Patak ${ }^{1}$, Jana Kostalova ${ }^{1}$, Marie Bednarikova ${ }^{1}$
}

\begin{abstract}
There are a lot of factors affecting employee motivation in the company. Some of them are supported by law, while others result from voluntary activities of the company, and the way to some of them still have not been found. Our research dealt with one of the possibilities, the S-LCA indicators as employee motivation factors. The attention is usually paid to companies and their system of employee stimulation. This research is supported by in-depth literature review in the field of S-LCA. Our research addressed employees of one medium-sized company to find out what they think of the activities of their management in the area of stimulation of their employees. Using a factor analysis, we found seven basic motivation factors, i.e. Safety at Work, Fair Remuneration, Social Security and Benefits, Work Climate, Basic Rights and Freedoms, Corporate Image, and Equal Opportunity. In the context of social impacts of manufacturing on employees, individual employee groups are motivated to work in different ways.
\end{abstract}

Key Words: motivation of employees, S-LCA, employee's satisfaction, social impact

\section{Introduction}

Basis to any explanation of why people behave in a certain manner is a theory of motivation (Lawler 1969). Employee motivation is a systematic process, within which managers permanently encourage and stimulate internal motivation of their subordinates in the way that they identify and apply such approaches, tools, and measures that help to satisfy the goals and needs of these employees, and thus they support their appropriate behaviour and improved job performance. The benefits to employees of such processes are direct but also lie in the way they make the work itself more motivating and enable them to deploy and grow their skills (Boxall, Hutchison \& Wassenaar 2015). This study offers a new look at employee motivation through Social Life Cycle Assessment (S-CLA). S-LCA, is a method that can be used for assessment of social and sociological aspects, their actual and potential benefits, as well as their negative impacts through the product life cycle (Andrews 2009; Dreyer 2006). Hence, the paper aims to identify employee motivation factors in the context of S-LCA method.

Motivation of employees - Each company more or less deals with what it should do to achieve a permanently high level of personal performance (Boxall 1994; Brewster 1993; Guest \& Hoque 1994; Schmidt \& Frieze 1997). It is understandable as it is a question of the company's survival on the market. This means that it is necessary to pay increased attention to employee stimulation, i.e. to deal with work they perform and the conditions in which this work is performed. In the general concept, motivating can be defined as a process of keeping, strengthening and orientating inner motivations through internal and 
also external stimulations, tools, and proceedings. Motivating is thus an intentional and permanent process the goal of which consists of creation of convenient conditions and application of convenient motivational approaches, tools, events and arrangements. These help to satisfy the employees' inner aspirations, goals and needs, and must be targeted at harmonization of individual motivational tendencies with divisional and organizational ones (Blaskova 2010). Arnold at al. (1991) defines three components of motivation: direction (what a person tries to achieve), effort (how hardworking they are when they try to achieve it), and persistence (how long they try to achieve it). People are motivated when they expect that certain steps will probably lead to achievement of a goal and acquisition of the appropriate reward, which will satisfy their needs. Schoen (2015) desccribes how expectations of differing types of evaluations and knowledge of the domain moderate the relationship between implicit achievement motivation and creativity. Results, measured implicitly, are related to creative performance. Employees need to remain motivated also from a long-term point of view (Zavadsky, Hitka \& Potkany 2015). Bogoyavlenskaya (2013) emphasizes key importance of Leontiev's structure of activity - operation, action, activity - for understanding the nature of creativity as the level of activity is realized on the basis of dominant motivation and leads to its development.

Motivation to work can be achieved either through internal motivation, where people seek, find, and perform a job that satisfies them by themselves, or they can be stimulated by their management through various methods (Bednarikova, Kostalova \& Glazarova 2019). There are several links between the leadership style and work motivation (Bronkhorst, Steijn \& Vermeeren 2015). Understanding the relationship between transformational leadership and creativity helps supervisors to create a work environment that fosters employee creativity (Henker, Sonnentag, Unger 2015). It is also possible to say definitely that there is a relationship between the pay level satisfaction and employee outcomes (Schreurs, Guenter, van Emmerik \& et al. 2015). We can say, that relationship between pay level satisfaction and employee outcomes exists (Schreurs, Guenter, van Emmerik \& et al. 2015).

There are a number of approaches to motivation. The most influential ones include: Instrumentality theory - it says that so-called sugar plum and whip policy, i.e. rewards and punishments, serves for making people behave and act in a required way (Skinner 1974). This theory originated in Taylor's methods of scientific management (1911), and it basically says that people work for money only.

Content-oriented theory - it focuses on the contents of motivation and is known as the need theory; whose authors are Maslow (1954) and Herzberg (1968). The Herzberg theory has given rise to a mass of investigations and experiments in industry and in many different types of organisations. The fecundity of the theory is not in doubt but its purity certainly is highly suspect (Gardner 1977). Another well-known theory is Alderfer's ERG Theory (1969), which refers to the needs for existence, relatedness, and growth. Another specific motivation theory is McClelland's (1975) acquired needs theory, which is based on studying managers and their three most important needs - needs for success, affiliation and power. Also, it is not possible to omit a specific needs theory - competence theory (White 1959). Employees should be assigned adequate tasks, which should not significantly exceed the level of their abilities and skills and which are not in contradiction to their 
values to prevent the feeling of frustration and loss of motivation to work. These theories are based on the fact that the contents of motivation consist of needs and each type of behaviour is motivated by unsatisfied needs. The best-known is Maslow's theory of motivation even though it has not been proven by empirical research.

Process theories - they focus on psychological processes that affect motivation and relate to expectancy (Vroom 1964), goals (Latham \& Locke 1979), and perception of equity (Adams 1965). These theories are more realistic than the need theory, and they deal with the fact how people perceive their work environment and the ways how they interpret and understand it. Expectancy (or the expectancy theory) is based on the existence of the relation between performance and outcome. As Lawler (1990) says, it is necessary that the link between effort and reward is obvious. The goal theory says that motivation and performance are higher is individuals are assigned with specific targets, if these targets are demanding, but acceptable, and that there is a response to performance. Erez and Zidon (1984) have emphasized the need for acceptation of targets and making a commitment to meet them. Robertson et al. (1992) says that goals inform the person about the level of the required performance, feedback makes it possible for them to monitor how well they worked and, if need be, to adjust their efforts to fulfil the goals. The equity theory (Adams 1965) deals with the fact how people perceive how they are treated compared to the other people (Goodman \& Friedman 1971). Equity relates to feelings and perception, and it is always a matter of comparison.

In the working environment, the employer focuses on development and achievement of derived needs using stimulation programmes. The need for self-actualization at work or the need for recognition by the superior and the colleagues are the employees' drivers. If an employee is not sufficiently motivated to reach a certain performance target, the result is usually not very satisfactory. The same negative consequences can result from excessive motivation. An employee tries to complete an assignment, and this often results in overworking or fatigue. Therefore, incentive processes must involve adequate motivation (McClelland \& Watson 1973). Its intensity needs to be assessed correctly. It is always derived from the given position, the situation in the workplace, and the employee's personality. Exceeding of the optimal rate of motivation results in so-called overmotivation, i.e. an inadequate degree of internal stress that has negative effects on our psyche and results in noncorresponding or insufficient performance.

Motivation theories represent emphasizing the importance of motivating an employee for better work performance. There are a lot of work behaviour motivation theories and they are very extensive. McGregor's Theory (1960), describing X and Y limit employee types is considered as a popular theory rather than a scientific one. In his concept, employee $\mathrm{X}$ is unreliable, irrational, and lazy. Employee $\mathrm{Y}$ is creative, independent, and willing to continually develop. The author points out the fact that the possibility of making use of the knowledge of the needs of the managed employees is very useful within their management (McClelland 1978). However, achieving this knowledge is a very demanding issue, particularly regarding the manager's time and communication skills, and so it is worth achieving it if the work team is stable. This theory is not valid generally, but what is its scientific benefit is the fact that it is necessary to allow for human psyche and diversity of human behaviour at work. Affiliation theory, or motivation theory of belongingness, developed by American psychologist Schachter (1959), emphasizes just the importance of 
social aspects of human behaviour for motivation. If a manager achieves the situation that it is a habit at their workplace to work at full engagement and creates the sense of belonging in the workplace, a new employee is also likely to be impressed by the majority and to start working at the same pace, at least in order to satisfy the employer's requirements. Individual differences in the reaction to a certain situation at work can be marked as work attitudes. Psychologists are not unanimous regarding the fact whether work attitudes are rather the result of congenital dispositions and so they are based on certain personality traits, or whether they are a product of the situation the employee occurs in (Brayfield \& Crockett 1955). Apart from different personality profiles, work attitudes of employees are also related to their motivation, which turns their behaviour to a certain direction. In the case of influencing or a change in attitudes, it is necessary, except for argumentation and explanation, to affect employees' emotions (McClelland 1996) as the emotional component of the attitude is stable and interconnected with the personal values and beliefs.

To achieve good performance at work, motivation itself is not enough (Guest 1984). The prerequisite for employee performance has three basic components: competency - I am capable, conditions - I can, and motivation - I want (Leontiev 2003; Burt 1954). The spectrum of stimulation factors at work is relatively wide. It includes e.g. bonuses or other rewards (also non-monetary), prestige jobs, the possibility of professional growth, good working conditions, or a suitable system of benefits. What is also important for employees is existence of feedback from their managers (Erez 1977) and good level of interpersonal relations between colleagues. Also, it is not possible to omit employee assessment, including an assessment interview, as a strong stimulation corporate activity. A modern approach to motivation can be seen in the Four Drive Model, which proposes four types of drives - sensual, material, emotional and spiritual (Shafi, Khemka \& Choudhury 2016). The history of motivation theory and research has seen a search for the "right" theory. It has been assumed that if such a theory was found, a wide range of behaviours would be better understood. A lot of models have been examined (Landy \& Becker 1987). It is always necessary to keep in mind that each human is unique, so it is important to consider their motives carefully and find a suitable way how to strengthen their motivation. It means answering a number of questions - what person is standing in front of me, what their motivation is, what stimulation system I should choose. What is the target the chosen approach should meet, what situation we occur in, and what are our possibilities and means we could make use of. It is thus not easy to choose the right approach to achieve employee satisfaction at all (Sulivan 1989). What is most important for a company is to find an approach that will strengthen job satisfaction of their employees.

Job satisfaction - Human satisfaction consists of at least three layers we must consider personal, process and material. The material layer refers to the result I would like to achieve, the process layer to the way that leads to it, and the personal layer to the role an individual play in the process. Motivation and job satisfaction are closely related (Bednarikova, Patak \& Souckova 2014). If a person is dissatisfied with their job, they can hardly be stimulated. A human evaluates the activity they do and also the fact what place this activity occupies in their life (Kalleberg \& Loscocco 1983). This evaluation is affected by the social environment the person grew up in. A person's job satisfaction profile is 
never unambiguous. In multiform relationships a human is affected by, some of them are crucial and decisive, some are less significant and some are neutral. Some relationships calm an employee down or stimulate strongly, while some other disturb or incapacitate them. Employee satisfaction has a lot of impacts on the company - it is reflected in the quality of production, it affects customer satisfaction, employee turnover, absence from work, and employee loyalty. Enterprises striving for increasing performance cannot expect that they will meet this target with employees who are dissatisfied.

The term job satisfaction refers to attitudes and feelings people have in their relationships with their jobs. In the general concept, we can consider job satisfaction as a favourable or positive emotional relation that is based on evaluation of a job or job experience (Cooper 1973). The term job satisfaction cannot be expressed by unambiguous characteristics, as it is a very large area (Porter et al. 1974). It essentially includes all the employee's displays in relation to the performed job, to the job placement and to the profession, to the working conditions, working environment, to the workplace, the work group and the entire company (Buchanan 1987; Hackman \& Oldham 1974, McClelland \& Franz 1992). We can understand it as satisfaction of employees with their jobs and working conditions, or as a necessary prerequisite for effective utilization of workforce. From the point of view of an employee, satisfaction can be connected with self-actualization, delight in work, but on the other hand also with certain self-satisfaction and subsequent passivity. Locke (1984) defines job satisfaction at a more general level as a pleasant or positive emotional condition, resulting from recognition of one's own work or job experience.

Theoretical approaches to job satisfaction can be divided according to the fact whether satisfaction is understood as a one-dimensional phenomenon (Maslow 1954) or a twodimensional phenomenon (Herzberg et al. 1957). In the one-dimensional concept, satisfaction ranges from maximum satisfaction to absolute dissatisfaction within one plane. A two-dimensional approach works with two groups of factors. The first group refers to the contents of the job itself and it is called a motivation group, the second group consists of factors expressing external conditions of the job activity (the physical environment, safety at work, the reward system, the management style, the work group, etc.). In this approach, satisfaction and dissatisfaction are two independent terms. The terms that are discriminated within this approach are internal satisfaction and no satisfaction, and external dissatisfaction and no dissatisfaction. For instance, a salary does not necessarily affect satisfaction, but it significantly contributes to dissatisfaction if it is low. We could expect that high job satisfaction will correspond to work behaviour of which high productivity, low absenteeism, and low turnover are typical. However, the practice shows that this relation is not that simple and straightforward. The truth is that in most cases good working conditions stimulate motivation to work. It is the same even in the case a person finds the content of their job itself satisfactory and rewarding. However, a completely opposite proportion is true if satisfaction is based on a low level of demands employees place on themselves, on the other people, and on the working conditions. Motivation at work then decreases.

Apart from monitoring satisfaction, it is important to monitor employee devotion to the company. The term devotion refers to the rate of employee ties and loyalty to the company. Mowday et al. (1982) says that devotion has three components: identification with corporate targets and values, desire to belong to the company, and willingness to make 
efforts in its favour. An employee can be satisfied in the company for a number of reasons, which however do not have to follow their intentions. Employee devotion, which is based on a psychological bond, makes it possible to better forecast future employee behaviour, which significantly affects not only the performance, but also turnover tendencies. Examining job satisfaction is very difficult as the key problem is to obtain truthful answers from respondents. The thing is that their answers are often distorted due to their fear of the impacts of the survey outcomes, and so respondents often answer in the way they think they are expected to.

We have examined a number of published studies dealing with a research into employee satisfaction in a lot of industries. These studies are based on usual motivation essentials, which mostly include money, the possibility of career growth, education opportunities, working conditions, and the supervisor's approach (e.g. Taylor et al. 2013, Kowal et al. 2015, Kaban et al. 2014, Coetzee et al. 2015, Ivanova et al. 2013, Augner 2015, Mihalcea 2013). A relatively wide range of satisfaction factors is offered by Hitka, where we can find some extra factors, e.g. psychical load at work, awareness of the work outcomes, or leisure time (Hitka et al. 2015). Our team tried to find and assess employee motivation and job satisfaction factors in accordance with the S-LCA methodology.

S-LCA indicators - Companies more and more often face the problems concerning their social behaviour. It is expected that companies will take over broader responsibility for the impacts of their business activities (Vavra, Munzarova \& Bednarikova 2015). Social impacts a company has on its surroundings and employees were summarised in a document published by the institution of PROSA (Product Sustainability Assessment), where they are divided into the following categories: safe and healthy working conditions, freedom of association and the right to collective bargaining, equality of opportunity and fair treatment, forced labour, child labour, adequate working hours, fair remuneration, social welfare, job security, professional development, and job satisfaction. Within these areas, particular indicators were defined for monitoring. However, their monitoring is usually not directly bound to a product. These impacts indicate corporate social responsibility, but usually they are rarely communicated outwardly (Tetrevova 2018). But in fact, these activities should contribute to the positive atmosphere in the company and, at the same time, to attract new quality employees (Jelinkova et al. 2016). Also, it is necessary to mention that a number of activities leading to improvements in working conditions and employee satisfaction are co-financed by the European funds (Kostalova \& Tetrevova 2018).

\section{Area under study}

The research involved a medium-sized company (Vasickova, 2015), which has developed not only from the point of view of its business, but also from the social point of view for the period of its existence. It affects its surroundings on a daily basis, and it is well aware of these impacts. Therefore, it is interested not only in its employees, but also in its surroundings, whose quality of life is significantly affected by the company. The research only examined impacts that can be commented on by the selected group of employees. 
The primary research aimed to (i) compare social impacts of manufacturing on employees according to the rate of their influence on employee motivation, (ii) identify the main components of social impacts of manufacturing on employees (i.e. motivation factors), and (iii) verify whether the identified factors affect employee motivation differently depending on their selected characteristics (sex, age, education, job, length of professional experience, and income). To achieve the targets, a quantitative survey was conducted in the form of personal questioning using a structured questionnaire. The data were collected among the employees of a selected chemical company. The company has been operating in the market for a quarter of a century. It is a sole manufacturing plant of a foreign group, which owns the company, and it manufactures luxurious cosmetic products for personal and hair care (hygiene). The owner is a global leading manufacturer and supplier of hotel cosmetics and accessories for hotels, ocean liners and airlines. Its products are delivered to more than 110 countries worldwide.

\section{Methodology}

110 employees (i.e. 39\%) were addressed within the questioning. 63 of them delivered their answers (the questionnaire response rate is $58 \%$ ). The respondents marked an arbitrary number of social impacts that affect their motivation to work in their current job most from offered 28 options. The list of social impacts was created on the basis of classification and specification of social impacts under the S-LCA methodology (GRI, 2013).

The following social impacts were assessed: workplace injury prevention; occupational disease prevention; measures solving the noise and dust loading rate, insufficient lighting, etc.; measures taken to maintain and ensure continuous enhancement of safety and health, systematic risk mitigation; access to clean drinking water and sanitary facilities; corporate support in the fight against significant local health problems (e.g. alcohol or drug addiction, AIDS, etc.); enabling association and collective bargaining, free elections of representatives of these associations; prevention of discrimination resulting from membership in trade unions or any other associations; provision of equal opportunity when applying for a job (prevention of discrimination because of sex, skin colour, age, religion, political orientation); employing the bodily handicapped; protection against stalking and bullying; observance of the ban on forced labour (i.e. labour for which a person gets no remuneration and he/she performs it against his/her will and under physical or psychological duress, threat of loss of the job or transfer to a worse job, etc.); observance of the ban on child labour (i.e. child labour preventing them from going to school, which is tiring, dangerous, below the limit of 15 years of age); observance of minimum wages and remuneration stipulated by law; observance of corporate minimum salary; keeping wages and salaries on the level ensuring a decent standard of living for the employee and their family; the salary corresponds to the demands and risks of the job; transparent remuneration (setting clear and unambiguous remuneration rules); timely payment of wages and salaries; observance of the set number of working hours in a working week; observance of the paid leave; making it possible to arrange working hours on an individual basis; offering employee benefits in the area of personal security (complementary pension insurance, sick-leave insurance, accident, health or life insurance); offering financial support (loans, discounts on the company products or services); assistance in the area of 
personal needs (holidays, child care, career interruption - studies, maternity leave); provision of a company car, mobile phone or credit card, meal or clothes allowances; provision of benefits contributing to the quality of the working environment (enhancement of workplace ergonomics, conditions and design - improvements in the look and functionality in the workplace); provision of benefits increasing the employer attractiveness (job security - low employee turnover, provision of benefits also for temporary or seasonal workers, support of professional development, organization of company events and celebrations, arrangement of transport to and from work, assistance with finding accommodation, etc.); another answer.

\section{Data collection}

The respondents taking part in the research specified their sex, age, highest achieved education, job, length of professional experience, and income (their monthly salary). See the structure of the research sample in Table 1.

Table 1: The Structure of the Research Sample

\begin{tabular}{|c|c|c|c|}
\hline Characteristics & Category & Frequency & $\begin{array}{l}\text { Percentage } \\
(\%)\end{array}$ \\
\hline \multirow{2}{*}{ Sex } & Male & 21 & 33 \\
\hline & Female & 42 & 67 \\
\hline \multirow{4}{*}{ Age } & Up to 25 years of age & 10 & 16 \\
\hline & $26-35$ & 19 & 30 \\
\hline & $36-45$ & 18 & 29 \\
\hline & 46 and older & 16 & 25 \\
\hline \multirow{4}{*}{ Education } & Elementary & 5 & 8 \\
\hline & Secondary without the Maturita exam & 26 & 41 \\
\hline & Secondary with the Maturita exam & 23 & 37 \\
\hline & Tertiary & 9 & 14 \\
\hline \multirow{3}{*}{ Job } & manufacturing operator & 39 & 62 \\
\hline & administrative worker & 15 & 24 \\
\hline & manager & 9 & 14 \\
\hline \multirow{4}{*}{ Experience } & Up to 1 year & 11 & 18 \\
\hline & $1-5$ years & 11 & 18 \\
\hline & $5-10$ years & 25 & 39 \\
\hline & More than 10 years & 16 & 25 \\
\hline \multirow{4}{*}{ Income } & Up to CZK15,000 & 17 & 27 \\
\hline & CZK15,001 - 20,000 & 23 & 37 \\
\hline & CZK20,001 - 25,000 & 12 & 19 \\
\hline & CZK25,001 and more & 11 & 17 \\
\hline Total & $\mathrm{x}$ & 63 & 100 \\
\hline
\end{tabular}

The data were processed by descriptive and inferential statistics using the statistical software package of IBM SPSS Statistics (v. 24). The rate of influence of the respective social impact on employee motivation was evaluated through the frequency of cases where the given social impact was marked in the questionnaire. The motivation factors were subsequently extracted using the exploratory factor analysis (extraction method: principal 
component analysis; rotation method: Varimax with Kaiser Normalization) and the acquired values of factor loadings in the rotated component matrix were used as the basis for interpretation of motivation factors. The average of standardized factor scores was used to show the differences in the intensity of the motivation factors in various groups of employees. The statistical significance of the differences was verified by ANOVA test at the 0.05 level of significance.

\section{Results and Discussion}

Table 2 contains the outcomes of the analysis of employee attitudes towards the researched social impacts (see target " $i$ "). The social impacts are arranged in the table in descending order according to the frequency of cases where the given social impact was marked in the questionnaire (percentage of cases).

Table 2: Comparison of social impacts according to the rate of their influence on employee motivation

\begin{tabular}{|l|l|l|l|}
\hline \multirow{2}{*}{ Social impact } & Responses & \multirow{2}{*}{$\begin{array}{l}\text { Percent of } \\
\text { Cases (\%) }\end{array}$} \\
\cline { 2 - 3 } & $\mathbf{N}$ & $\begin{array}{l}\text { Percent } \\
\mathbf{( \% )}\end{array}$ & \\
\hline Wage/salary ensures a decent standard of living & 35 & 7.8 & 56 \\
\hline Timely payment of wage/salary & 35 & 7.8 & 56 \\
\hline Employer attractiveness & 33 & 7.4 & 52 \\
\hline Employee benefits in the area of personal security & 31 & 6.9 & 49 \\
\hline Enabling individual arrangement of working hours & 28 & 6.3 & 44 \\
\hline Assistance in the area of personal needs & 28 & 6.3 & 44 \\
\hline Quality of the working environment & 27 & 6.0 & 43 \\
\hline Transparent remuneration & 23 & 5.1 & 37 \\
\hline $\begin{array}{l}\text { Observance of the stipulated length of working hours in a working } \\
\text { week }\end{array}$ & 23 & 5.1 & 37 \\
\hline Observance of the length of paid leave & 22 & 4.9 & 35 \\
\hline Material employee benefits & 17 & 3.8 & 27 \\
\hline Observance of the minimum wage and remuneration stipulated by law & 16 & 3.6 & 25 \\
\hline Wage/salary corresponds to the job demands or risks & 16 & 3.6 & 25 \\
\hline Measures solving the rate of noise and dust loading, insufficient lighting & 15 & 3.3 & 24 \\
\hline $\begin{array}{l}\text { Measures taken to maintain and continuously increase safety and health } \\
\text { protection }\end{array}$ & 14 & 3.1 & 22 \\
\hline Observance of the ban on forced labour & 10 & 2.2 & 16 \\
\hline Access to clean drinking water and sanitary facilities & 9 & 2.0 & 14 \\
\hline Protection against stalking and bullying & 9 & 2.0 & 14 \\
\hline Workplace injury prevention & 8 & 1.8 & 13 \\
\hline Enabling association and collective bargaining & 8 & 1.8 & 13 \\
\hline Observance of the corporate minimum wage/salary & 8 & 1.8 & 13 \\
\hline Occupational diseases prevention & 7 & 1.6 & 11 \\
\hline Provision of equal opportunity when applying for a job & 7 & 1.6 & 11 \\
\hline Offering financial support & 7 & 1.6 & 11 \\
\hline $\begin{array}{l}\text { Prevention of discrimination resulting from membership in trade } \\
\text { unions or other associations }\end{array}$ & 5 & 1.1 & 8 \\
\hline Corporate support in the fight against significant local health problems & 3 & 0.7 & 5 \\
\hline Employment of the bodily handicapped & 3 & 0.7 & 5 \\
\hline Observance of the ban on child labour & 1 & 0.2 & 2 \\
\hline
\end{tabular}


\begin{tabular}{|l|l|l|l|}
\hline Total & 448 & $x$ & 100 \\
\hline Table 2 implies that, out of 28 offered options, the respondents on average marked 7 social
\end{tabular} impacts that influence their motivation to work most. Each of the offered social impacts was marked at least by one respondent. However, high variability of responses shows that the respondents' attitudes to social impacts are very different. More than a half of the respondents marked the social impacts of "Wage/salary ensuring a standard of living", "Wage/salary paid in time", and "Employee attractiveness". This means that social impacts directly relating to employee remuneration have the biggest impact on employee motivation at the researched company. On the other hand, the social impacts of "Corporate support in the fight against significant local health problems", "Employment of the bodily handicapped", and "Observance of the ban on forced labour" were marked by the respondents in less than $5 \%$ of the cases. Therefore, these are social impacts having, compared to the other examined alternatives, the smallest influence on employee motivation at the company.

Due to a large number of the researched social impacts whose perceived importance mutually significantly correlated at the same time, an exploratory factor analysis was conducted to identify the main components of the social impact of manufacturing on the employees (i.e. motivation factors, see target "ii"). Application of the factor analysis to the research data not only decreased the total number of considered social impacts, but the applied factor analysis procedure also ensured that they were statistically independent. The criteria for choosing the number of factors were the simplicity of the model interpretation and sufficient total variance explained by the model. Regarding these goals, the optimal number of factors according to Eigenvalues was reduced to a value of 7 . In the models with a lower number of factors, the total communality falls below $60 \%$, some of variables cannot be sufficiently explained (the factor loadings are less than 0.4 ), and the model interpretation is quite misleading. Table 3 contains the initial Eigenvalues and the variance explained.

Table 3: Initial Eigenvalues

\begin{tabular}{|l|l|l|l|}
\hline Number of factors & Eigenvalue & $\begin{array}{l}\text { Variance } \\
\text { Explained }\end{array}$ & $\begin{array}{l}\text { Cumulative Variance Explained } \\
\mathbf{( \% )}\end{array}$ \\
\hline 1 & 5.604 & 20.0 & 20.0 \\
\hline 2 & 3.644 & 13.0 & 33.0 \\
\hline 3 & 2.344 & 8.4 & 41.4 \\
\hline 4 & 1.986 & 7.1 & 48.5 \\
\hline 5 & 1.715 & 6.1 & 54.6 \\
\hline 6 & 1.448 & 5.2 & 59.8 \\
\hline 7 & 1.323 & 4.7 & 64.5 \\
\hline 8 & 1.255 & 4.5 & 69.0 \\
\hline 9 & 1.085 & 3.9 & 72.9 \\
\hline 10 & 1.009 & 3.6 & 76.5 \\
\hline 11 & 0.923 & 3.3 & 79.8 \\
\hline 12 & 0.704 & 2.5 & 82.3 \\
\hline 13 & 0.676 & 2.4 & 84.7 \\
\hline 14 & 0.572 & 2.0 & 86.7 \\
\hline 15 & 0.522 & 1.9 & 88.6 \\
\hline 16 & 0.485 & 1.7 & 90.3 \\
\hline 17 & 0.462 & 1.7 & 92.0 \\
\hline
\end{tabular}




\begin{tabular}{|l|l|l|l|}
\hline 18 & 0.394 & 1.4 & 93.4 \\
\hline 19 & 0.350 & 1.3 & 94.6 \\
\hline 20 & 0.301 & 1.1 & 95.7 \\
\hline 21 & 0.264 & 0.9 & 96.7 \\
\hline 22 & 0.236 & 0.8 & 97.5 \\
\hline 23 & 0.186 & 0.7 & 98.2 \\
\hline 24 & 0.150 & 0.5 & 98.7 \\
\hline 25 & 0.140 & 0.5 & 99.2 \\
\hline 26 & 0.114 & 0.4 & 99.6 \\
\hline 27 & 0.072 & 0.3 & 99.9 \\
\hline 28 & 0.036 & 0.1 & 100.0 \\
\hline
\end{tabular}

When interpreting the motivation factors, we worked on the presumption that the factor loading value corresponds to the strength of the correlation relationship between the examined social impact and the latent motivation factor. The performed analysis thus made it possible to identify seven motivation factors, i.e. Safety at Work (Factor 1), Fair Remuneration (Factor 2), Social Security and Benefits (Factor 3), Work Climate (Factor 4), Basic Rights and Freedoms (Factor 5), Corporate Image (Factor 6), and Equal Opportunity (Factor 7). Table 4 contains the factor loading matrix of the factor analysis rotated solution (factor loadings with a value lower than 0.4 are not included in the matrix).

Table 4: Rotated Component Matrix

\begin{tabular}{|c|c|c|c|c|c|c|c|}
\hline Social impact & 1 & 2 & 3 & 4 & 5 & 6 & 7 \\
\hline $\begin{array}{l}\text { Measures taken to maintain and continuously } \\
\text { increase safety and health protection }\end{array}$ & 0.770 & & & & & & \\
\hline $\begin{array}{l}\text { Access to clean drinking water and sanitary } \\
\text { facilities }\end{array}$ & 0.738 & & & & & & \\
\hline Workplace injury prevention & 0.659 & & & & & & \\
\hline Occupational diseases prevention & 0.647 & & & & & & \\
\hline $\begin{array}{l}\text { Measures solving the rate of noise and dust } \\
\text { loading, insufficient lighting }\end{array}$ & 0.595 & & & & & & \\
\hline $\begin{array}{l}\text { Observance of the stipulated length of } \\
\text { working hours in a working week }\end{array}$ & 0.530 & 0.473 & & & & & \\
\hline $\begin{array}{l}\text { Wage/salary corresponds to the job demands } \\
\text { or risks }\end{array}$ & & 0.792 & & & & & \\
\hline Transparent remuneration & & 0.753 & & & & & \\
\hline $\begin{array}{l}\text { Wage/salary ensures a decent standard of } \\
\text { living }\end{array}$ & & 0.663 & & & & & \\
\hline Observance of the length of paid leave & 0.494 & 0.590 & & & & & \\
\hline Material employee benefits & & 0.557 & & & & & \\
\hline Timely payment of wage/salary & & 0.440 & & & & & \\
\hline Employer attractiveness & & & 0.819 & & & & \\
\hline $\begin{array}{l}\text { Employee benefits in the area of personal } \\
\text { security }\end{array}$ & & & 0.746 & & & & \\
\hline Assistance in the area of personal needs & & & 0.677 & & & & \\
\hline Offering financial support & & & 0.401 & & & & \\
\hline Enabling association and collective bargaining & & & & 0.777 & & & \\
\hline $\begin{array}{l}\text { Enabling individual arrangement of working } \\
\text { hours }\end{array}$ & & & 0.563 & 0.583 & & & \\
\hline $\begin{array}{l}\text { Observance of the minimum wage and } \\
\text { remuneration stipulated by law }\end{array}$ & & & & 0.515 & & & \\
\hline
\end{tabular}




\begin{tabular}{|l|l|l|l|l|l|l|l|}
\hline Quality of the working environment & & & & 0.513 & & & \\
\hline Observance of the ban on child labour & & & & & 0.731 & & \\
\hline Observance of the ban on forced labour & & & & & 0.590 & & \\
\hline Protection against stalking and bullying & & & & 0.472 & 0.523 & & \\
\hline $\begin{array}{l}\text { Observance of the corporate minimum } \\
\text { wage/salary }\end{array}$ & & & & & & 0.765 & \\
\hline $\begin{array}{l}\text { Corporate support in the fight against } \\
\text { significant local health problems }\end{array}$ & & & & & & 0.652 & \\
\hline Employment of the bodily handicapped & & & & & 0.529 & 0.584 & \\
\hline $\begin{array}{l}\text { Provision of equal opportunity when applying } \\
\text { for a job }\end{array}$ & & & & & & & 0.779 \\
\hline $\begin{array}{l}\text { Prevention of discrimination resulting from } \\
\text { membership in trade unions or other } \\
\text { associations }\end{array}$ & & & & 0.595 & & & 0.615 \\
\hline
\end{tabular}

The following inverse solution to the factor analysis made it possible to specify the value of factor scores for each respondent and each motivation factor. At the same time, the average factor score in a group was calculated for each group of employees (depending on their characteristics). As the acquired factor scores have standard normal distribution $\mathrm{N}$ $(0,1)$, the negative value of average represents a weaker effect in the group, while the positive value represents a stronger effect in the group. The differences in the intensity of the motivation factor effects were analysed in all the examined employee characteristics (sex, age, highest achieved education, job, experience, and monthly salary, see Target "iiii"), i.e. validity of 42 partial hypotheses about the independence of the effects of motivation factors ( 7 factors) from the employee characteristics ( 6 characteristics) were verified. The following Tables 5-10 contain the verified hypotheses, the average factor scores in employee groups, and the results of the hypothesis testing (ANOVA test at the 0.05 level of significance).

Table 5: Influence of sex on employee motivation

\begin{tabular}{|l|l|l|l|l|}
\hline \multirow{2}{*}{ Hypothesis } & \multicolumn{2}{|l|}{ Average factor score } & $\begin{array}{l}\text { P- } \\
\text { value }\end{array}$ & Result \\
\cline { 2 - 6 } & Men & Women & & \\
\hline $\begin{array}{l}\text { H1a: Influence of the factor of Safety } \\
\text { at Work is independent of the } \\
\text { employee's sex }\end{array}$ & -0.359 & 0.179 & 0.043 & Rejected \\
\hline $\begin{array}{l}\text { H1b: Influence of the factor of Fair } \\
\text { Remuneration is independent of the } \\
\text { employee's sex }\end{array}$ & 0.344 & -0.172 & 0.053 & Supported \\
\hline $\begin{array}{l}\text { H1c: Influence of the factor of Social } \\
\text { Security and Benefits is independent } \\
\text { of the employee's sex }\end{array}$ & -0.024 & 0.012 & 0.895 & Supported \\
\hline $\begin{array}{l}\text { H1d: Influence of the factor of Work } \\
\text { Climate is independent of the } \\
\text { employee's sex }\end{array}$ & -0.105 & 0.052 & 0.561 & Supported \\
\hline $\begin{array}{l}\text { H1e: Influence of the factor of Basic } \\
\text { Rights and Freedoms is independent } \\
\text { of the employee's sex }\end{array}$ & -0.012 & 0.006 & 0.946 & Supported \\
\hline $\begin{array}{l}\text { H1f: Influence of the factor of } \\
\text { Corporate Image is independent of } \\
\text { the employee's sex }\end{array}$ & -0.167 & 0.084 & 0.352 & Supported \\
\hline
\end{tabular}




\begin{tabular}{|c|c|c|c|c|}
\hline $\begin{array}{l}\text { H1g: Influence of the factor of Equal } \\
\text { Opportunity is independent of the } \\
\text { emplovee's sex }\end{array}$ & 0.160 & -0.080 & 0.373 & Supported \\
\hline
\end{tabular}

While factor "Fair Remuneration" has a bigger influence in men, as for women, it is factor "Safety at Work" what has a stronger effect. In both cases the hypothesis verification was at the limit of significance, but the identified difference can only be considered as significant in the case of factor "Safety at Work".

Table 6: Influence of age on employee motivation

\begin{tabular}{|l|l|l|l|l|l|l|}
\hline \multirow{2}{*}{ Hypothesis } & \multicolumn{2}{|l|}{ Average factor score } & \multicolumn{1}{|l|}{$\begin{array}{l}\text { P- } \\
\text { value }\end{array}$} & Result \\
\cline { 2 - 8 } & $\begin{array}{l}\text { Up to } \\
\mathbf{2 5}\end{array}$ & $\mathbf{2 6 - 3 5}$ & $\mathbf{3 6 - 4 5}$ & $\begin{array}{l}\mathbf{4 6} \text { and } \\
\text { more }\end{array}$ & & \\
\hline $\begin{array}{l}\text { H2a: Influence of the factor of Safety } \\
\text { at Work is independent of the } \\
\text { employee's age }\end{array}$ & 0.277 & -0.406 & 0.080 & 0.219 & 0.189 & Supported \\
\hline $\begin{array}{l}\text { H2b: Influence of the factor of Fair } \\
\text { Remuneration is independent of the } \\
\text { employee's age }\end{array}$ & 0.011 & 0.107 & -0.109 & -0.012 & 0.936 & Supported \\
\hline $\begin{array}{l}\text { H2c: Influence of the factor of Social } \\
\text { Security and Benefits is independent } \\
\text { of the employee's age }\end{array}$ & 0.241 & 0.145 & -0.297 & 0.012 & 0.472 & Supported \\
\hline $\begin{array}{l}\text { H2d: Influence of the factor of Work } \\
\text { Climate is independent of the } \\
\text { employee's age }\end{array}$ & 0.251 & 0.053 & -0.014 & -0.205 & 0.724 & Supported \\
\hline $\begin{array}{l}\text { H2e: Influence of the factor of Basic } \\
\text { Rights and Freedoms is independent } \\
\text { of the employee's age }\end{array}$ & -0.655 & 0.153 & 0.157 & 0.051 & 0.155 & Supported \\
\hline $\begin{array}{l}\text { H2f: Influence of the factor of } \\
\text { Corporate Image is independent of } \\
\text { the employee's age }\end{array}$ & -0.430 & -0.038 & -0.111 & 0.439 & 0.158 & Supported \\
\hline $\begin{array}{l}\text { H2g: Influence of the factor of Equal } \\
\text { Opportunity is independent of the } \\
\text { employee's age }\end{array}$ & -0.053 & -0.196 & -0.160 & 0.446 & 0.223 & Supported \\
\hline
\end{tabular}

The intensity of the influence of factor "Work Climate" tends to decrease with a growing age, while the intensity of the influence of factor "Corporate Image" increases together with the age. Significantly high factor scores were detected in the oldest employee group (46 years of age and more) in factor "Equal Opportunity", which reflects the sensitivity of employees in this age group to the issue of discrimination of job applicants (e.g. for the reason of an old age). On the other hand, a very low motivation potential was identified in factor "Basic Rights and Freedoms" in the youngest age group employees (up to 25 years of age). In view of a low respondent frequency in respective employee groups, it is not possible to consider any of the above results as statistically significant.

Table 7: Influence of education on employee motivation

\begin{tabular}{|l|l|l|l|}
\hline Hypothesis & Average factor score & $\begin{array}{l}\text { P- } \\
\text { value }\end{array}$ & Result \\
\hline
\end{tabular}




\begin{tabular}{|l|l|l|l|l|l|l|}
\hline & Primary & $\begin{array}{l}\text { Secondary } \\
\text { without } \\
\text { Maturita }\end{array}$ & $\begin{array}{l}\text { Secondary } \\
\text { with } \\
\text { Maturita }\end{array}$ & Tertiary & & \\
\hline $\begin{array}{l}\text { H3a: Influence of the factor of } \\
\text { Safety at Work is independent } \\
\text { of education achieved by the } \\
\text { employee }\end{array}$ & 0.288 & 0.104 & -0.029 & -0.385 & 0.572 & Supported \\
\hline $\begin{array}{l}\text { H3b: Influence of the factor of } \\
\text { Fair Remuneration is } \\
\text { independent of education } \\
\text { achieved by the employee }\end{array}$ & -0.697 & -0.233 & 0.216 & 0.509 & 0.060 & Rejected \\
\hline $\begin{array}{l}\text { H3c: Influence of the factor of } \\
\text { Social Security and Benefits is } \\
\text { independent of education } \\
\text { achieved by the employee }\end{array}$ & -0.009 & -0.347 & 0.063 & 0.847 & 0.018 & Rejected \\
\hline $\begin{array}{l}\text { H3d: Influence of the factor of } \\
\text { Work Climate is independent } \\
\text { of education achieved by the } \\
\text { employee }\end{array}$ & -0.472 & 0.165 & -0.207 & 0.314 & 0.301 & Supported \\
\hline $\begin{array}{l}\text { H3e: Influence of the factor of } \\
\text { Basic Rights and Freedoms is } \\
\text { independent of education } \\
\text { achieved by the employee }\end{array}$ & 0.174 & -0.250 & 0.201 & 0.114 & 0.428 & Supported \\
\hline $\begin{array}{l}\text { H3f: Influence of the factor of } \\
\text { Corporate Image is } \\
\text { independent of education } \\
\text { achieved by the employee }\end{array}$ & 1.208 & -0.248 & 0.123 & -0.271 & 0.016 & Rejected \\
\hline $\begin{array}{l}\text { H3g: Influence of the factor of } \\
\text { Equal Opportunity is } \\
\text { independent of education } \\
\text { achieved by the employee }\end{array}$ & 0.709 & 0.028 & -0.178 & -0.021 & 0.359 & Supported \\
\hline
\end{tabular}

Statistically significant influence of education on employee motivation was verified in three cases. The intensity of the effects of factors "Fair Remuneration" and "Social Security and Benefits" increases together with the achieved level of employee's education. What is more important for employees with higher education is material and social security. On the other hand, the intensity of factor "Corporate Image" decreases with increasing education, which shows higher sensitivity of employees with lower education to the perceived corporate image and reputation.

Table 8: Influence of the job on employee motivation

\begin{tabular}{|l|l|l|l|l|l|}
\hline \multirow{2}{*}{ Hypothesis } & \multicolumn{2}{|l|}{ Average factor score } & $\begin{array}{l}\text { P- } \\
\text { value }\end{array}$ & Result \\
\cline { 2 - 6 } & $\begin{array}{l}\text { Manufacturing } \\
\text { Operators }\end{array}$ & $\begin{array}{l}\text { Office } \\
\text { Staff }\end{array}$ & Managers & & \\
\hline $\begin{array}{l}\text { H4a: Influence of the factor of } \\
\text { Safety at Work is independent of the } \\
\text { employee's job }\end{array}$ & 0.184 & -0.440 & -0.065 & 0.117 & Supported \\
\hline $\begin{array}{l}\text { H4b: Influence of the factor of Fair } \\
\text { Remuneration is independent of the } \\
\text { employee's job }\end{array}$ & -0.123 & 0.036 & 0.475 & 0.271 & Supported \\
\hline
\end{tabular}




\begin{tabular}{|l|l|l|l|l|l|}
\hline $\begin{array}{l}\text { H4c: Influence of the factor of } \\
\text { Social Security and Benefits is } \\
\text { independent of the employee's job }\end{array}$ & -0.330 & 0.592 & 0.445 & 0.002 & Rejected \\
\hline $\begin{array}{l}\text { H4d: Influence of the factor of } \\
\text { Work Climate is independent of the } \\
\text { employee's job }\end{array}$ & -0.092 & 0.003 & 0.396 & 0.425 & Supported \\
\hline $\begin{array}{l}\text { H4e: Influence of the factor of Basic } \\
\text { Rights and Freedoms is } \\
\text { independent of the employee's job }\end{array}$ & -0.182 & -0.045 & 0.863 & 0.016 & Rejected \\
\hline $\begin{array}{l}\text { H4f: Influence of the factor of } \\
\text { Corporate Image is independent of } \\
\text { the employee's job }\end{array}$ & -0.103 & -0.086 & 0.588 & 0.163 & Supported \\
\hline $\begin{array}{l}\text { H4g: Influence of the factor of } \\
\text { Equal Opportunity is independent } \\
\text { of the employee's job }\end{array}$ & 0.068 & -0.140 & -0.063 & 0.780 & Supported \\
\hline
\end{tabular}

Employees in managerial positions are, compared to the other employees, more significantly affected by all motivation factors (with the exception of factors "Safety at Work" and "Equal Opportunity"). However, a statistically significant influence of the job on employee motivation was only verified in factors "Social Security and Benefits" and "Basic Rights and Freedoms". In both cases, these factors more often motivate employees in managerial positions, but factor "Social Security and Benefits" is of the strongest influence in office employees.

Table 9: Influence of experience on employee motivation

\begin{tabular}{|l|l|l|l|l|l|l|}
\hline \multirow{2}{*}{ Hypothesis } & \multicolumn{2}{|l|}{ Average factor score } & \multicolumn{1}{|l|}{$\begin{array}{l}\text { P- } \\
\text { value }\end{array}$} & Result \\
\cline { 2 - 7 } & $\begin{array}{l}\text { Up to 1 } \\
\text { year }\end{array}$ & $\begin{array}{l}\mathbf{1 - 5} \\
\text { years }\end{array}$ & $\begin{array}{l}\text { 5-10 } \\
\text { years }\end{array}$ & $\begin{array}{l}\text { More } \\
\text { than 10 } \\
\text { years }\end{array}$ & & \\
\hline $\begin{array}{l}\text { H5a: Influence of the factor of Safety } \\
\text { at Work is independent of the } \\
\text { employee's experience }\end{array}$ & 0.138 & -0.144 & 0.084 & -0.127 & 0.838 & Supported \\
\hline $\begin{array}{l}\text { H5b: Influence of the factor of Fair } \\
\text { Remuneration is independent of the } \\
\text { employee's experience }\end{array}$ & 0.046 & 0.480 & -0.146 & -0.134 & 0.343 & Supported \\
\hline $\begin{array}{l}\text { H5c: Influence of the factor of Social } \\
\text { Security and Benefits is independent } \\
\text { of the employee's experience }\end{array}$ & 0.286 & -0.584 & 0.140 & -0.014 & 0.161 & Supported \\
\hline $\begin{array}{l}\text { H5d: Influence of the factor of Work } \\
\text { Climate is independent of the } \\
\text { employee's experience }\end{array}$ & -0.135 & -0.006 & 0.161 & -0.156 & 0.753 & Supported \\
\hline $\begin{array}{l}\text { H5e: Influence of the factor of Basic } \\
\text { Rights and Freedoms is independent } \\
\text { of the employee's experience }\end{array}$ & -0.230 & -0.163 & 0.064 & 0.169 & 0.707 & Supported \\
\hline $\begin{array}{l}\text { H5f: Influence of the factor of } \\
\text { Corporate Image is independent of } \\
\text { the employee's experience }\end{array}$ & 0.078 & -0.291 & -0.029 & 0.192 & 0.667 & Supported \\
\hline $\begin{array}{l}\text { H5g: Influence of the factor of Equal } \\
\text { Opportunity is independent of the } \\
\text { employee's experience }\end{array}$ & 0.160 & 0.293 & -0.115 & -0.132 & 0.618 & Supported \\
\hline
\end{tabular}


The data analysis did not identify any trends between the intensity of motivation factor effects and the employees' experience. At the same time, none of the detected differences was statistically significant, and so the acquired data support, in all the cases, the hypothesis of the independence of employee motivation on the length of their experience at the company.

Table 10: Influence of the salary on employee motivation

\begin{tabular}{|l|l|l|l|l|l|l|}
\hline \multirow{2}{*}{ Hypothesis } & \multicolumn{2}{|l|}{ Average factor score } & $\begin{array}{l}\text { P- } \\
\text { value }\end{array}$ & Result \\
\cline { 2 - 7 } & $\begin{array}{l}\text { Up to } \\
\text { CZK }\end{array}$ & $\begin{array}{l}\text { CZK } \\
\mathbf{1 5 , 0 0 1 -} \\
\mathbf{2 0 , 0 0 0}\end{array}$ & $\begin{array}{l}\mathbf{C Z K} \\
\mathbf{2 0 , 0 0 1}-\mathbf{2 5 , 0 0 0}\end{array}$ & $\begin{array}{l}\text { More } \\
\text { than } \\
\mathbf{C Z K} \\
\mathbf{2 5 , 0 0 0}\end{array}$ & & \\
\hline $\begin{array}{l}\text { H6a: Influence of the factor of Safety } \\
\text { at Work is independent of the } \\
\text { employee's salary }\end{array}$ & 0.442 & 0.089 & -0.554 & -0.264 & 0.043 & Rejected \\
\hline $\begin{array}{l}\text { H6b: Influence of the factor of Fair } \\
\text { Remuneration is independent of the } \\
\text { employee's salary }\end{array}$ & -0.076 & -0.313 & 0.322 & 0.422 & 0.134 & Supported \\
\hline $\begin{array}{l}\text { H6c: Influence of the factor of Social } \\
\text { Security and Benefits is independent } \\
\text { of the employee's salary }\end{array}$ & 0.108 & -0.279 & -0.006 & 0.423 & 0.270 & Supported \\
\hline $\begin{array}{l}\text { H6d: Influence of the factor of Work } \\
\text { Climate is independent of the } \\
\text { employee's salary }\end{array}$ & 0.247 & -0.114 & -0.158 & 0.030 & 0.659 & Supported \\
\hline $\begin{array}{l}\text { H6e: Influence of the factor of Basic } \\
\text { Rights and Freedoms is independent } \\
\text { of the employee's salary }\end{array}$ & -0.441 & -0.014 & -0.074 & 0.792 & 0.013 & Rejected \\
\hline $\begin{array}{l}\text { H6f: Influence of the factor of } \\
\text { Corporate Image is independent of } \\
\text { the employee's salary }\end{array}$ & -0.111 & -0.006 & 0.085 & 0.093 & 0.944 & Supported \\
\hline $\begin{array}{l}\text { H6g: Influence of the factor of Equal } \\
\text { Opportunity is independent of the } \\
\text { employee's salary }\end{array}$ & -0.223 & 0.263 & 0.174 & -0.395 & 0.213 & Supported \\
\hline
\end{tabular}

The intensity of the effects of factor "Safety at Work" tends to decrease together with the decreasing salary, while the intensity of the influence of factors "Basic Rights and Freedoms" and "Corporate Image" increases together with the salary. In the case of factors "Safety at Work" and "Basic Rights and Freedoms", the difference is statistically significant.

\section{Conclusions}

The research into the S-LCA method as a tool for corporate management decision-making our group has been dealing with for a few years included the relation between employee motivation and social aspects of corporate activities, which are quantified by indicators recommended for utilization within the S-LCA methodology. An important group of these indicators are those evaluating social aspects in connection with the impact of corporate activities on the group of stakeholders who are employees. 
Within the literature review, we found a number of researches dealing with employee motivation factors affecting employee satisfaction at work. These researches were inspiration for composing our own scale of factors, as we wanted to have this set as wide and complete as possible. We compared individual social impacts of manufacturing according to the rate of their influence on employee motivation, and we identified the main motivation factors. Using a factor analysis, we finally identified seven basic motivation factors, i.e. Safety at Work, Fair Remuneration, Social Security and Benefits, Work Climate, Basic Rights and Freedoms, Corporate Image, and Equal Opportunity. This outcome is in harmony with a number of researches performed in the past.

Individual employee groups are motivated to work in different ways. The research showed that from the examined respondent characteristics, it is their education what has the biggest impact on employee motivation. Statistically significant differences were identified in the effects of three out of seven motivation factors. As for Fair Remuneration and Social Security and Benefits, the influence of these factors grows together with an increasing level of education. The third factor is Corporate Image, to which employees with lower education are more sensitive. We consider these outcomes adequate in chemical companies, where work is connected with a certain risk and it is perceived as very dangerous.

The future research could bring an interesting analyses of motivation factors, especially after the pandemic of COVID-19. It will be beneficial to focus on evaluation of the changes of employee's attitudes based on their current experience of changing conditions due to COVID-19. It is possible to expect the changes in the structure of the main motivation factors, an increase in the importance of Safety in Work, Social Security and Benefits and an increase in the preference of other factors, which have been strongly influenced by pandemic of COVID-19. There will be useful comparison of different industries/areas due the impact of COVID-19 pandemic has been different in the different areas and in the different countries.

\section{References}

Adams, J.S. (1965). Injustice in Social Exchange. In: Berkowitz, L. (ed): Advances in Experimental Psychology, Vol 2, Academic Press, New York.

Alderfer, C. P. (1969). Job Enlargement and Organizational Context. Personnel Psychology, 22/4, 418-427.

Andrews, E.S. et al. (2009). Guidelines for Social Life Cycle Assessment of Products. Paris, United Nations Environment Programme.

Arnold, J., Robertson, I.T. \& Cooper, C.L. (1991). Work Psychology. Pitman, London.

Augner, Ch. (2015). Job Satisfaction in the European Union; The Role of Macroeconomic, Personal, and JobRelated Factors. Journal of Occupational and Environmental Medicine, 57/3, 241-245.

Bednarikova, M., Patak, M. \& Souckova, L. (2014). Satisfaction of Company Employees. Human Resources Management and Ergonomics, 1, 33-45.

Bednarikova, M., Kostalova, J. \& Glazarova, M. (2019). Modern Trends in Human Resource Management in the Czech Chemical Companies. Sci. Pap. Univ. Pardubice, Ser. A, 2019, 141-156.

Blaskova, M. (2010). Creative Proactive-concluding Theory of Motivating. Business: Theory and Practice, 11/1, $39-48$.

Bogoyavlenskaya, D. B. (2013). Voprosy Psikhologii, 3, 101-111, 05-06.

Boxall, P. (1994). Placing HR strategy at the heart of the business. Personnel Management, July, 32-35. 
Boxall, P., Hutchison, A. \& Wassenaar, B. (2015). How do High-involvement Work Processes Influence Employee Outcomes? An Examination of the Mediating Roles of Skill Utilisation and Intrinsic Motivation. International Journal of Human Resources Management, 26/13, 1737-1752.

Brayfield, A.H. \& Crockett, W.H. (1955). Employee attitudes and employee performance. Psychological Bulletin, $52,346-424$.

Brewster, C. (1993). Developing a „European“ model of human resource management. The International Journal of Human Resource Management, 4/4, 765-784.

Bronkhorst, B., Steijn, B. \& Vermeeren, B. (2015). Transformational Leadership, Goal Setting, and Work Motivation: The Case of a Dutch Municipality. Review of Public Personnel Administration, 35/2, 124-145.

Buchanan, D. (1987). Job enrichment is dead: long live high performance work design! Personnel Management, May, 40-43.

Burt, C. (1954). The Differentiation of Intellectual Ability. British Journal of Educational Psychology, 24.

Coetzee, M. \& Stoltz, E. (2015). Employees' satisfaction with retention factors: Exploring the role of career adaptability. Journal of Vocational Behaviour, 89, 83-91.

Cooper, R. (1973). Task characteristics and intrinsic motivation. Human Relations, August, 387-408.

Dreyer, L.C. et al. (2006). A Framework for Social Life Cycle Impact Assessment. Retrieved from: $<$ http://www.saiplatform.org/uploads/Library/FrameworkforSocialLCA.pdf>.

Erez, M. (1977). Feedback: a necessary condition for the goal-setting performance relationship. Journal of Occupational Psychology, 62/5, 624-627.

Erez, M. \& Zidon, I. (1984). Effect of Good Acceptance on the Relationship of Goal Difficulty on Performance. Journal of Applied Psychology, 69/1, 69-78.

Gardner, J. (1977). Is there a valid test of Herzberg's two-factor theory? J. Occupational Psychology, 50, 197.

Goodman, P.S. \& Friedman, A. (1971). An Examination of Adams' Theory of Inequity'. Administrative Science Quarterly. http://www.jstor.org/stable/2391900

GRI (2013). What is GRI? (on line). Retrieved from: < https://www.globalreporting.org/information/aboutgri/what-is-GRI/Pages/default.aspx>.

Guest, D.E. (1984). What's new in motivation. Personnel Management, May, 30-33.

Guest, D.E. \& Hoque, K. (1994). Yes, personnel management does make the difference. Personnel Management, November, 40-44.

Hackman, J.R. \& Oldham, G.R. (1974). Motivation through the design of work: test of a theory. Organizational Behaviour and Human Performance, 16/2, 250-279.

Henker, N., Sonnentag, S. \& Unger, D. (2015). Transformational Leadership and Employee Creativity: The Mediating Role of Promotion Focus and Creative Process Engagement. Journal of Business and Psychology, 30/2, 235-247.

Herzberg, F.W., Mausner, B. \& Snyderman, B. (1957). The Motivation to Work. Wiley, New York.

Herzberg, F. (1968). One More Time: How do you Motivate Employees. Harvard Business Review, 01-02, 109120.

Hitka, M., Závadská, Z. \& Jelačic', D. \& Balážová, Ž. (2015). Qualitative Indicators of Company Employee Satisfaction and Their Development in a Particular Period of Time. Drvna Industrija, 66 (3), 235-239.

Ivanova, T. Y. \& Rasskazova, E. I. (2013). Socio-demographic and organizational factors of job satisfaction. Psychologičeskij žurnal, 34/6, 40-52.

Jelinkova, M., Munzarova, S. \& Lostakova, H. (2016). Internet CSR Presentation and its Importance for Increasing Corporate Reputation in the Area of Ferrous Metallurgy. In: 25th International Conference on Metallurgy and Materials „METAL 2016“, Ostrava: Tanger, 1829-1837.

Kaban, K. E., Sen, A., Gocer, K., Kucuksoylemez, S. \&, Tuncer, G. (2014). Strategies for employee job satisfaction: A case of service sector. Procedia - Social and Behavioral Science, 150, 1167-1176.

Kalleberg, A.L. \& Loscocco, K.A. (1983). Aging, values and rewards: explaining age differences in job satisfaction. American Sociological Review, 48.

Kostalova, J. \& Tetrevova, L. (2018). Co-financing of Projects of Chemical Companies in the Czech Republic from EU Sources. Chemické Listy, 112(11), 790-794.

Kowal, J. \& Roztocki, N. (2015). Job satisfaction of IT professionals in Poland: does business competence matter? Journal of Business Economics and Management, 16/5, 995-1012, doi: 10.3846/16111699.2014.924988

Landy, F.J. \& Becker, W.S. (1987). Motivation Theory Considered. Research in Organizational Behaviour, 1/1987, $1-38$. 
Latham, G. \& Locke, R. (1979). Goal setting: motivational technique that works. Organizational Dynamics, Autumn, 68-80.

Lawler, E.E. (1969). Job Desing and Employee Motivation. Personnel Psychology, 22/4, 426-435.

Lawler, E.E. (1990), Strategic Pay. Jossey-Bass, San Francisco (CA).

Leontiev, A.N. (2003). The problem of ability (on the subject of B.M. Teplov's notes about his review of the chapter for the coursebook). Voprosy Psykhologii, 2, 20-30.

Locke, E.A. (1984). Effect of self-efficacy, goals and task strategies on task performance. Journal of Applied Psychology, 69/2, 241-251.

Maslow, A. (1954). Motivation and Personality. Harper \& Row, New York.

McClelland, D. (1975). Power, The Inner Experience. Irvington, New York.

McClelland, D.C. (1996). Human motivation: A social psychological approach. Contemporary Psychology, 41/5, 443-444.

McClelland, D.C. \& Franz, C.E. (1992). Motivational and other sources of work accomplishments in midlife - a longitudinal-study. Journal of Personality, 60/4, 679-707.

McClelland, D.C. (1978). Managing motivation to expand human freedom. American Psychologist, 33/3, 201 210.

McClelland, D.C. \& Watson, R.I. (1973). Power motivation and risk-taking behaviour. Journal of Personality, 41/1, 121-139.

McGregor, D. (1960). The Human Side of Enterprise. McGraw-Hill, New York.

Mihalcea, A. (2013). The Impact of Leader's Personality on Employees' Job Satisfaction. Procedia - Social and Behavioral Science, 78, 90-94.

Mowday, R., Porter, L. \& Steers, R. (1982). Employee-Organization Linkages: The Psychology of Commitment, Absenteeism and Turnover. Academic Press, London.

Porter, L.W., Steers, R., Mowday, R. \& Boulian, P. (1974). Organizational commitment, job satisfaction and turnover amongst psychiatric technicians. Journal of Applied Psychology, 59, 603-609.

Robertson, I.T., Smith, M. \& Cooper, D. (1992). Motivation. Institute of Personnel Management, London.

Schreurs, B., Guenter, H., van Emmerik, I.J. \& Hetty et al. (2015). Pay Level Satisfaction and Employee Outcomes: the Moderating Effect of Autonomy and Support Climates. International Journal of Human Resources Management, 26/12, 1523-1546.

Shafi, A.A., Khemka, M. \& Choudhury, S.R. (2016). A new approach to motivation: Four-drive model. Journal of Human Behavior in the Social Environment, 26/2, 217-226.

Schachter, S. (1959). The Psychology of Affiliation. Stanford University Press, Stanford.

Schmidt, L.C. \& Frieze, I.H. (1997). A mediational model of power, affiliation and achievement motives and product involvement. Journal of Business and Psychology, 11/4, 425-446.

Schoen, J.L. (2015). Effects of Implicit Achievement Motivation, Expected Evaluations, and Domain Knowledge on Creative Performance. Journal of organizational behavior, 36/3, 319-338.

Skinner, B.F. (1974). About Behauviourism. Knopf, New York.

Sulivan, J.J. (1989). Self Theories and Employee Motivation. Journal of Management, 15/2, 345-363.

Taylor, F. W. (1911). Principles of Scientific Management. Harper, New York.

Taylor, P., McLoughlin, Ch., Meyer, D. \& Brooke, E. (2013). Everyday discrimination in the workplace, job satisfaction and psychological wellbeing: age differences and moderating variables. Ageing and society, 33, 1105-1138, doi: 10.1017/So144686X12000438.

Tetrevova, L. (2018). Communicating Socially Responsible Activities of Chemical Companies in the Czech Republic. Chemické Listy, 112, 122-127.

Vasickova, A. (2015). Evaluation of Social Indicators in the Company from the Perspective of Employees'. University of Pardubice, diploma thesis.

Vavra, J., Munzarova, S. \& Bednarikova, M. (2015). Assessment of Social Impacts of Chemical and Food Products in the Czech Republic. In: S. S. Muthu (ed.). Social Life Cycle Assessment, an Insight (pp. 147-197). Springer, Singapore.

Vroom, V. (1964). Work and Motivation. Wiley, New York.

White, R.W. (1959). Motivation reconsidered. The concept of Competence. Psychological Review, 66/5, 297 333.

Zavadsky, J., Hitka, M. \& Potkany, M. (2015). CHanges of Employee Motivation of Slovak Enterprises Due to Global Economic Crisis. E\&M Ekonomie a Management, 18/1, 57-66. 